\title{
Mida arvasid Oskar Loorits ja teised õpetatud eesti mehed eestlaste iseloomust
}

Avaldatud: Mis on see ISE: Tekst, tagapõhi, isikupära / toim: Maie Kalda, Õnne Kepp. Tallinn: Eesti Teaduste Akadeemia Underi ja Tuglase Kirjanduskeskus, 1999, lk 96-118

(Collegium litterarum 11)

\section{1.}

Ühe või teise hõimu, rahva või rahvuse iseloomu piiritlemine või määritlemine on juba antiikajal - aga vististi varemgi - olnud nii kroonikakirjutajate kui ka reisimeeste meelistegevusi. Vahest kõige tuntum sedalaadi kirjatöö on Tacituse "Germania". On küll väidetud, et germaanlaste idealiseeritud iseloomustamisega tahtnud Tacitus alla kriipsutada langusaegse Rooma kodanike eetilis-moraalset allakäiku. Küllap võib otsida teosele muidki seletusi.

Eestlastegi kohta on ajalookirjanduses Henrikust peale antud rohkesti hinnanguid. Vanemad hinnangud tunnukse üsna üheülbalised; enamasti rõhutatakse visa kinnihoidmist paganlusest. Mitmekülgsemaks muutuvad iseloomustused siis, kui Baltimaadesse jõuab Euroopa valgustusaja mõju. Seoses seisukohavõttudega pärisorjuse kohta kujuneb välja kaks vastandlikku käsitust: orjuse pooldajad näevad eestlastes (ja lätlastes) ennekõike või ainult negatiivset; orjuse vastased osundavad negatiivset orjuse tagasimõjuna, otsides ja leides selle kõrval ka positiivseid jooni (nt. muusikaarmastus). Oleks üsnagi huvitav vanemast kirjandusest välja noppida ja reastada meile omal ajal antud iseloomustusi, mis kajastaksid nii ajajärgu mõju kui ka iseloomustaja suhtumisi. Kahtlemata oleks neist kasu ka võrdlemisel hilisemate autoritega, kes on söandanud käsitleda nii vaieldavat küsimust kui ühe rahvuse iseloomustus enne Looritsat.

Teadupärast on Mihkel Kampmaa esimese eestlasena (1902) püüdnud arutada teemal eestlase iseloom ja laad. M. Kampmaa peab vajalikuks eristada temperamenti (iseloomu) ja karakterit (laadi), kuivõrd esimene on looduse and, teine aga kasvatuse tulemus. Temperamendilt olla eestlased "kurbmeelsed" ehk melanhoolsed: "Nukrus, leinamine, rahutu meel ja kaebtused elukibeduse üle on kurbmeelelise iseloomu tundemärgid. Kurbmeelne armastab üksindust ja kõik, mis kõrge, kole, tume ja mis sügav ning mõtterikas on. Sellepärast on 
ta teaduses ja kunstis tihti tähtjas tööline. Kurbmeelse iseloomu hääd küljed on tundmuse sügavus, sisemine rahu, ettevõtete kindel täidesaatmine ja puhtad püüdmised." (3, 10-11). Mööndes paljude karakteriomaduste päritavust, rõhutab ta kasvatuse ja hariduse mõju, mis karakteriomadusi pehmendavad või koguni teisendavad. Rahvakarakterist kõneldes lubab ta peatuda nendel joontel, mis eestlasi teistest rahvastest lahutavad, mis meid eestlasteks teevad $(3,14)$. Materjalina kasutab M. Kampmaa eesti ajalugu, vanavara, kirjandust, praegust elujärge ja võrdlusi teiste rahvaste esindajate arvamustega. Muuseas väidab ta, et eestlased on pigem tunde- kui mõistuseinimesed (toetudes paraku "Kalevipojast" võetud näidetele).

Esmalt peatub M. Kampmaa eesti karakteri positiivsetel omadustel. Siin nimetab ta kõigepealt usust johtuvat vagadust (3, 34); teisena vanemate austust. Mõistagi seostab M. Kampmaa - J. Hurda eeskujul - vanemate austamise ja armastamise keele, kommete, vaimuvara ja selle kaudu rahvuse austamisega $(3,38)$. Näitena nimetab ta arvukaid eesti asundusi Venemaal, mis on säilitanud oma keele, omad kombed ja oma rahvuse. "Iseäraline kaunis karakteri omadus, mis eestlast ehitab, on tema tööhimu ja virkus, hoolsus ja kokkuhoidmine, mida naabrirahvaste juures vähemal mõõdul leiame" $(3,41)$. Veel toob ta esile "tahtmise kindluse ehk energia, pikaldase sügava järelemõtlemise, loomuliku mõistuse ja tõsise meele" (3, 43-44). Edasi leiab ta, et "eestlane on ettevõtete täitmises aeglane, järelemõtleja, ettevaatlik ja avaldab palju loomulikku tarkust" $(3,46)$. Näiteiks toob ta arvukalt vanasõnu. Julgesti väidab M. Kampmaa: "Kurbmeelse iseloomuga eestlane ei salli kerget meelt, narrust, halpust, välimisi tühje kombeid, vaid armastab selle vastu tüsedust, tõemeelt, kohtlust ja otsekohesust" $(3,47)$. Veel nimetab ta eestlase karsket meelt, kainust, vahvust ja julgust, südamehäädust, truudust ja lahket võõraste vastuvõtmist $(3,48)$. Lõpuks viitab ta eestlase igatsusele au ja kuulsuse järele. Võõraste järgi iseloomustavat eestlasi "jutuajamise armastus ja pilkamise himu” $(3,49)$. M. Kampmaa kinnitab, et "kõnesid kuuleb eestlane hää meelega ja peab tublist kõnemehest suurt lugu"; kes rahva poolehoidu taotleb, "see peab kas hästi kõneleda või ilusasti muusikat teha oskama" $(3,50)$.

Nende positiivsete omaduste kõrval peatub M. Kampmaa ka eestlaste negatiivsetel karakteriomadustel. Esimesena nimetab ta siin hooplemist, pettust ja valet, teise ebavoorusena himu võõra omanduse järele. Kuritegude statistika järgi on vargused Eestis esikohal. Nimetatud omadustest johtub ka usaldamatus. Eriti märgib M. Kampmaa umbusaldust sakslaste vastu, leides selle põhjusi kodumaa ajaloost, s.o. orjaajast. Usaldamatusest johtub M. Kampmaa järgi ka üldine kahtlustamine ja ühenduse puudumine $(3,61)$. Väga iseloomulikuks peab ta visadust selle hoidmises, mis käes on, ja selle vastuvõtmises, mida pakutakse, ning visadusest lähtuvat kiusu ja jonni. Erapooletult nendib 
M. Kampmaa: "Pärispõlv vajutas eesti rahva vaimule oma raske käega pitserimärgi otsa ette, orjameel sai nii kui teiseks eestlase loomuseks...” (3, 62-63).

Raamatukese esimeses pooles ( $64 \mathrm{lk}$ ) vaeb M. Kampmaa eesti iseloomuomadusi, teises pooles (54 lk) aga arutleb võimalusi iseloomu parandamiseks, tõstes esile just kasvatuse osa. M. Kampmaa arutlustes on mõndagi, mis on aktuaalsed ka täna. Tema poolt esiletoodud iseloomuomadustes on küll vaieldavat, samuti vastuolulist. Näiteks eestlaste usuline vagadus on üpriski kaheldav; tõemeel ja otsekohesus on vastuolus pettuse ja valega; au ja kuulsuse igatsus pole vist spetsiifiliselt eesti iseloomu juurde kuuluv jne. Tema põhipuuduseks näikse aga ühepinnaline käsitus: eestlaste muistne hea iseloom on alla käinud, "orjaaja" pärandina nimetab ta jonni, kiusu ja orjameelt. ${ }^{1}$

Ometi on M. Kampmaa esimesena analüüsinud eesti rahvuslikku iseloomu. Küllap olnuksid tulemusedki tüsedamad, kui kasutada olnuks suurem ja usaldusväärsem materjal. Pole ju mõtet kasutada "Kalevipoega" rahvapärase allikana. Ka kirjandusteosena ei kajasta "Kalevipoeg" muistsete ega kaasaegsetegi eestlaste maailmasuhet. Tõlketeosena ei ütle Kreutzwaldi "Lembitu" midagi eesti rahva kohta. Üksikvanasõnade sõnasõnaline tõlgendamine on A. Krikmanni uurimuste põhjal (vt. näiteks vanasõnade akadeemilise väljaande "Sissejuhatus" lk. 55 jj.) vähemalt kaheldav (peaaegu igale vanasõnale võib vanasõnakorpusest leida ka otsese vastanduse, sestap tuleb arvestada a) vanasõnakorpust tervikuna, b) iga vanasõna populaarsust ja vanust). Seda kõike teame oma tänases tarkuses, M. Kampmaale oli see muidugi teadmata. Etteheide ongi mõeldud mitte autorile, vaid tema kasutatud ainesele.

Oma arvukatesse kirjutistesse on ka Juhan Luiga poetanud üht-teist eestlaste iseloomu kohta. Needki kirjutised - koondatud nüüd kogumikku "Mäss ja meelehaigus" - pärinevad sajandi algusest enne esimest suurt sõda. J. Luiga vaatleb arstiteadlasena oma kaasaegseid ja tuletab nende käitumisest, harrastustest ja tegevusest rahvusele iseloomulikku. Ajalukku põikab ta harva. Üldiselt on J. Luiga üpris kriitiline.

Teravalt ründab ta laialt levinud, peaaegu et iseloomujooneks saanud alkoholismi, pidades seda eesti rahva moraalseks surmaks. Ta nõuab täiskarskust ja kehalisi harjutusi $(7,93)$, vihjates, et rootslased on ennast terveks võimelnud. Arvestades vaimuhaiguste suurt määra (Tartu maakonnas üks 128 inimese kohta: 7, 54), rõhutab ta korduvalt, et ainult tervetel vanematel on terved järglased. Sellest tema paradoks "Mitte kasvatus üksi, vaid sündimine teeb inimese" $(7,94)$. Vihjamata otseselt nn tõutervishoiu teooriale, jääb ometi mulje, et Luiga seda teab, tunneb ja põhiliselt ka toetab.

J. Luiga nendib eestlaste nõrkust usu vallas ja leiab: "Lahkusulised püüded on loomulikud nähtused usuelu elavnemises." Ent ta hoiatab, et need püüded muutuvad kergesti usuliseks märatsemiseks (7, 99). Teisal - artiklis "Põhja- 
vaim" - viitab ta, et lahkusuliste püüdeks on kasvatada ekstaasikultust. Õige tihti olla usulise andega inimeste juures psühhopatoloogilist ollust märgata (7, 107). J. Luiga ütleb lausa, et ka muistne soome soo usk oli n.-ö. ateistlik: usuti mitte jumalaid, vaid saatust $(7,272)$.

Täiesti uudne ja omapärane on J. Luiga seisukoht, et rõõm on meie rahva edenemises olnud tähtsaks tõukejõuks $(7,245)$. Samas märgib ta, et rõõmus meel käib kaasas kehalise tervisega 7, 159).

Huvitav on võrdlev tähelepanek: lätlaste kergeusklikkus ja kiire vaimustumine on kaasa toonud poliitilisi kuritegusid (küsimuses oli 1905. a. revolutsioon); eestlaste juures on kriminaalkuritegusid poole rohkem. Just revolutsiooni ajal ilmnesid eestlaste tagasihoidlikkus, ettevaatlikkus ja iseloomutõsidus $(7,138)$. Ta viitab ka B. de Courtenay hinnangule eestlastest kui kainest ja teadusliku maailmavaatega rahvast. Üldistavalt märgib J. Luiga, et soome soo kangelaste ülimaks vooruseks, nende suuruseks oli tarkus. Samas leiab ta, et entusiasm pole eestlaste seast iial kadunud. Ometi peab ta vajalikuks hoiatada, et Eestis kipub peale jääma varavalminud raukade tarkus.

Rohket tähelepanu pöörab J. Luiga kultuurile. Päris samamoodi hilisema O. Looritsaga väidab J. Luiga, et kõige suurema sammu kultuuri poole tegid eestlased sellega, et valisid eluasemeks Läänemere ranniku (7, 186). Mitmes kirjutises märgib Luiga mererahva osa kultuuride vahendajana. Õigusega osundab Luiga, et seni on Eesti kultuuri käsitatud talupojakultuurina, mis on ühekülgne ja seega ekslik. Rahvuskultuur peab esindama tervet rahvast (7, 237). Ta möönab, et eestlased on oma ajaloo tõttu olnud ühe "seisuse" rahvus, mis teeb meie kultuuri arendamise keeruliseks ja raskeks. Ometi on kunst teinud seda, mida poliitika pole suutnud: 1869. a. laulupidu ühendas rahva. J. Köler, A. Weizenberg, A. Adamson olid omal alal esimesed mitte ainult Eestis, vaid tervel Venemaal, millest johtub ka nende rahvuslik tähtsus. Uuema aja ühendavateks teguriteks peab J. Luiga "Estonia" ja "Vanemuise" seltsi oma teatrimajadega $(7,246)$. Ta märgib paradoksina, et teatrimaja ei ehitata rahaga, vaid usaldusega. Igivana vastasseisu arvestajana rõhutab J. Luiga, et majanduse edendamine ei loo uut, seevastu kultuuri edenemine ongi uue loomine, uute väärtuste otsimine $(7,258)$.

Nagu näeme, ei sobi J. Luiga poolt tõdetu ühte kõigi M. Kampmaa väidetega. Kardinaalselt erineb nende hinnang eestlaste usklikkusele. Aga kas ongi siin põhjust imestada - üks oli ju arstiteadlane, teine köster-koolmeister! Rohkem võiks ehk imestada mõne kokkulangeva väite üle.

Iseseisvuse aastatel on iseloomustavat esile toodud vististi vähem arutlevas artiklis ja rohkem ilukirjanduses (tahtmatagi meenub näiteks H. Raudsepa "Mikumärdi"). Ometi, Johannes Semper alustab oma esseekogu "Prantsuse vaim" 1934. a. esseega "Prantsuse vaimulaad ja meie rahvuslik omapära". Ta 
möönab kohe: "Olen teadlik selles, kui hõlpsasti võib rahva omapära iseloomustades sattuda libedale teele” $(11,5)$ ja toob ka näiteid. Tõsi, ta ei näi arvestavat, et paljude hinnangute taga on rahvustevaheline riiklikult õhutatud ja kohati lausa rassistlik vastuolu.

J. Semper nendib, et eestlaste ja põhjasakslaste vahel leiab hõlpsasti ühiseid jooni. Arvestades sajanditepikkust saksa mõju pole see ka imekspandav. Seevastu venepärasus pole eestlastele külge jäänud. Ometi leiab J. Semper, et meie soomeugrilises aluspõhjas ja eestipärases kristallisatsioonis on saksapärasusele võõrast. Edasi peatub ta nendel iseloomuomadustel, mis eristavad eestlasi prantslastest: prantslaste elav temperament ei sarnane eestlaste pikatoimelisusega; loodus on prantslastele kui mitte vaenlane, siis vähemalt võõras - meil vastupidi; prantslane töötab mõõdukalt, meile on omane tööga liialdamine, mis eriti meie haritlaskonna erksama osa liiga vara läbi põletab. Meie tüüpiline töörühkija peab puhkeaega raisatud ajaks, lausa patuks. Vastandina prantslastele on meie toidus olulisem toitvus kui maitsvus ja kvaliteet. Meil taunitakse meeltelõbu: ilu on patt, meeled luksus. Kohvikuid, tantsu jne. mõistetakse hukka lausa vennastekogudusliku valjusega. Eestlane eelistab kohmakust peenusele, sõnatust või vähesõnalisust paisutatud lobisemisele. Liigne viisakus paistab meile teesklusena, tunnete paisutus - vigurdusena. Sõnade ilukõla tekitab eestlastes piinlikkust. Eestlastele on omane askeetlik hoiak. Eestlases on mahavaikitud tundmusi, väljendamata mõtteid, tumemeelsust ja raskusevaimu. "Kahtlemata kannab meie rahva vaimulaad jälgi, mida kauane majanduslik, sotsiaalne ja poliitiline rippuvus temasse jätnud, ja see, mida meie rahvuslikuks iseäralduseks peame, on suurelt jaolt tööloomaks ühtlustatud rahva ilming" $(11,26)$.

Artikli teises pooles osundab J. Semper ühisjoontele prantsuse ja eesti iseloomus. Ta viitab M. Bedeli täheldatud eestlaste kriitilisele meelele, irooniale ja individualismile; kordab B. de Courtenay hinnangut (sellest oli juttu J. Luiga puhul); edastab K. E. von Baeri hinnangu eestlastele - rahulik, külmavereline, tasakaalukas - ning H. Keyserlingi arvamuse - kainus, positivism, visadus. J. Semper üldistab: need loetletud omadused viitavad eestlase intellektuaalsusele. Ta rõhutab veel, et eestlasele jääb võõraks tugev kirg, meeletu afekt; seksuaalne pinge ja erootika on meil võrdlemisi kahvatu (siurulik ihaluule tundub juba liigjulgena), ekstsessid ja orgiad on meile olemusvõõrad; ka meie tundeluulele on võõrad kirglikud üleskutsed, tulisõnad, needused, hümnid ja oodid, ehtne paatos. Luteri kirikusse jäi mõistlikkus ja mõistuslikkus, usutunne valgus vennastekogudusse ja lahkuskudesse. Arukus, mõõdukus, kainus on meile niihästi loomuomased kui ka normatiivsed. Kriitiline meel tõi kaasa põlastuse naiivsuse, otskohtluse, lihtsa andumuse või millestki haaratuse vastu. Ent J. Semper nendib, et kainus kasvatab ka keskpärasust, ükskõiksust loovate 
ekstsesside vastu. "Intellektuaalsuse primaati tõendab ka alistumine ideedele ja enese ideedest juhtida laskmise suuril ajaloolistel käänakuil” (11, 29-30).

Kokkulangevusteks prantsuse meelelaadiga peab J. Semper esiteks arukust, teiseks staatilisust (ebaajaloolisust - näiteks rahvaluule), kolmandaks individualismi, neljandaks demokratismi ja humanismi. Väidete põhjendusena mainib ta tulevikuvormi puudumist eesti keeles, meie keelekorralduse ja ka keeleuuenduse ratsionalistlikest, rahvapärase luuleesituse ehk deklamatsiooni puudumist. Ta viitab, et nii prantsuse kui ka eesti keeles juriidilise termini õige aluseks on geomeetria (teistes keeltes seda ei oima). Ta järeldab, et me peaksime olema matemaatikas andekad, viidates eesti statistikale, mis olla maailma paremaid. Ta osutab, et soomlased olla eestlaste meelest naiivsed, eestlased aga soomlaste arvates skeptilised ja kriitilised. Esiletõstmist väärib J. Semperi osundus "ürgeestlasele ja anarhistile" Sotnikule (H. Raudsepa "Salongis ja kongis") kui sügavalt tabatud tüübile, milles on eesti iseloomule omast. J. Semperi vaimukas essee on M. Kampmaa raamatukese järel teine eesti rahvusliku iseloomu arutlus. Mõistagi on tunda, et teoseid lahutab mitte ainult 32 aastat, vaid ka iseseisvumisega kaasnenud kiire areng. J. Semperi väited on tõesemad, realistlikumad; argumendid põhjendatumad. Jätnud kõrvale iseloomu ajaloolise arengu domineerib tema esituses mis, mitte miks või kuidas.

\section{2.}

Rahvapsühholoogia, samuti rahvusliku iseloomu määratlemisel osutub oluliseks, kui mitte kõige tähtsamaks aines, millele toetuda. Kõige usaldatavam näikse siin olevat rahvaluule. Rahvapärimuste hulk, mis on talletatud Eesti Rahvaluule Arhiivis (1995. a. seisuga 1258583 lehekülge), võimaldab vaatlusi mitmest aspektist, ka sotsioloogilis-psühholoogilisi. Tõsi, materjali korraldamissüsteem on orienteeritud erialainimestele (selleski osas on veel vajakajäämisi). Teiste erialade uurijatele võib see korraldus osutuda raskepäraseks ja ebaülevaatlikuks. Seepärast ongi eesti folkloori tavapärasest vaatlusest põikuvad aspektid üpris haruldased. Reaalseks võimaluseks jääb esialgu see, et mõni folklorist ise vaatleb kogunenud ainest uudsest aspektist.

Sellise võimaluse on realiseerinud Oskar Loorits, kes oma rahvausundi ülevaate kokkuvõttes on kasutanud rahvapsühholoogilist analüüsi. Selle najal on ta skitseerinud eestlase (laiemalt läänemeresoomlase) iseloomu - võrdlevalt lääne e. aaria karakteriga.

Oma kontseptsiooni on ta esitanud "Grundzüge des estnischen Volksglaubens" kolmandas osas (1957). Populaarsemal kujul on ta samad seisukohad sõnastanud raamatukestes "Eestluse elujõud" (1951) ja "Eesti ajaloo põhi- 
probleemid" (1955). Erinevust on neis sedavõrd, et "Grundzüges" lähtub autor rahvausundist ja folkloorist, teistes teostes võtab ta appi ka ajaloolised, majanduslikud ja sotsiaalsed tegurid. Arvesse tulevad ka paljud artiklid, milles on käsitletud üht või teist joont eestlaste või laiemalt soomeugrilaste iseloomus. See probleem ilmub Looritsa kirjutistesse 30-ndatel aastatel ja on talle aktuaalne mitukümmend aastat. Tahaksin rõhutada kohe alguses, et Looritsa seisukohtadesse võib suhtuda kuidas tahes, ka täiesti eitavalt, kuid see on siiski hiigeltöö, mis äratab aukartust juba oma mõõtmetega. Mõistagi ei mõtle ma siin teose mahtu (mis on ka mammutlik: $591+490+690=1771 \mathrm{lk}$.), vaid käsitletud materjali hulka ja ulatust.

O. Loorits oli vist esimene, kes järjekindlalt rõhutas, et soomeugrilased olid metsarahvas. Mets on jätnud oma jälje ka neile, kes temas elasid. Mets eksitab, varjab perspektiive, ei soodusta loogikat, kaotab avarustunde ja suurejoonelisuse. Mets kasvatab kannatlikkust, pikameelsust, vastupidavust, visadust, vimma ja vaikimist. Mets teeb ettevaatlikuks, sisendab umbusku. Ent mets arendab ka tundeelu, impressionismi ja visionaarsust, tekitab fantaasiaerksust, mis võib kaasa tuua kaksikelu: tegelikkuses ja kujutluses. Mets ajendab intuitsiooni. Metsast johtub rütmitunne ja sellest taas musikaalsus. Mets teeb kargeks.

Mets ja põhjamaine ilm on soomeugrilaste väärtusteadvuses kujundanud mitmeid tahke. Talvised toidumured ja mahajäetustunne õpetasid säästmist ja ettemõtlemist, samuti ühtehoidmist ja solidaarsust kuni teadliku kooperatsioonini. Võimetustunne looduse ees ajendas kannatlikkust ja tunnustavat suhtumist kaasolevusse (vrd. germaani titaanide trotslik individualism). Suve-talve vaheldumine ajendas aarialasi nägema selles dualistlikku vastuolu (vrd. suve-talve võitlus germaanlastel), soomeugrilasi aga otsima sünteesi. Talv ei olnud igas mõttes vaenlane, vaid ka sõber ja abimees (vrd. vanasõna: talv teeb sillad soode pääle, madalate maade pääle). Soomeugrilasele oli omane pariteetsus, millega kaasnes kannatlikkus ja laialtmõistetud respekt erisuste ees (vanasõna: igal linnul ise viis, igal mehel oma meel). Eesti sotsiaaleetika kuldreegel avaldub vanasõnas: ela ise ja lase teistel kah elada! Selline mõtteviis viib paratamatult demokraatiani. Relatiivsuse tunnetamisest võrsub aga ka ühiskondliku lõtvuse idu. Kuna puuduvad kindlad normid, reeglid ja nõuded, siis nõrgeneb kogu sotsiaalpoliitiline struktuur. Soome-ugri seadusandlus pole tänini jõudnud sellise täpsuse ja viimistluseni nagu näiteks aaria ja altai rahvastel. See piirdus ebamäärase, üldsuunitlust andva tavaõigusega, mille tõlgendajateks olid vanemad - hõimuvaimsust esindav kollektiiv ja mille otsus ei olnud niivõrd karistus kui asja reguleerimine kõigi huvides. Karistuse ideoloogia on hilisem ja laenatud. Eesti muistendites esinev motiiv - viljavarga pea otsast kündmine - esineb sellisena Lüübeki õiguses, mis Tallinnas 1257. a. kehtima hakkas. 
Metsamiljöö on sisendanud julgust ja võimet või otsustavust olukordade lahendamiseks. See on olnud aluseks võimukale personalismile, mida omakorda on karastanud kaks loodusjõudu: tuli ja tuul. Ent ühtki loodusjõudu pole soomeugrilased jumalaks tõstnud. Oleks vale näha personalismis toonitatud individualismi, rõhutab Loorits. Vastupidi, ühiskondliku elu vormitus sunnib peale tõdemuse, et soomeugrilastel oli indiviidil väike tähtsus nii sotsiaalselt kui ka eetiliselt. Oluline faktor oli pere, sugukond, hõim, mis hoidis kontinuiteeti kuni ärkamisajani (Looritsal rahvuslik renessanss). Eestis kaotas see oma tähenduse alles XIX sajandil ja asendus osalt lausa haiglase individualismiga.

Ent metsamiljöö mõjus ka negatiivselt: metsaelus polnud võimalikki ühiskondlik liigendus või erinevad sotsiaalsed grupid. Elati eraldi, perede kaupa. Mets eraldas ja võõrandas. Metsas ei võrsunud individualism, vaid partikularism, separatism, detsentralisatsioon. On ilmne, et poliitika pole olnud ega ole praegugi meie olemuse tugevamaid külgi.

Jõudnud Läänemere äärde, astusid läänemeresoomlased suhtlusse germaanlastega. Loorits seob selle pronksiajaga ja nimetab esimeseks suureks murranguks soomeugrilaste (s.o. läänemeresoomlaste) vaimsuses. Mõistagi on see murranguaeg küllaltki pikk periood.

Looritsa järgi tõi see kaasa suurima muutuse just sotsiaalses elus: metsakultuuri asemele astus talupojakultuur, külakultuur. Meie vanimad kultuurtaimed on Looritsa väitel naeris, nisu, oder, vanim leiutis rehi ja vanimad pööripäeva märkivad pühad suvisted ja talvisted. Usundis tõi see kaasa surnute matmise (hiljem põletamise) - senise õhkmatuse asemel. Teisenes suhtumine surnusse (hakkas domineerima hirm laiba ees). Indogermaanlastelt on laenatud üksikuid usundilisi motiive, mitte uskumussüsteemi, mida peab rõhutama ikka ja jälle $(4,442)$.

Maa n.-ö. ehitati üles sugukonnaorganisatsioonina. Aluseks olid suurpered pered, mis moodustasid küla. Külad liitusid leppega (kihi) kihelkondadeks ja viimased maakondadeks. Tähtis ei olnud isik, vaid perekond. See ilmneb usundiski, ka loodusvaimud on rajatud perekondlikul printsiibil: isad-emad-lapsed. Ainult germaanipärastel veevaimudel kohtame kuningat, kes läänemeresoomlastel oli ainult kaaskonna sõjaline juht. Mõisted isand, vanem taanduvad perekonnale. Sotsiaalsed kohustused kajastuvad rahvausus üllatavalt napilt. Maalinnadest linnustest on muistendeid erakordselt vähe (nn. Kalevipojasängid).

Vaimsuse erisus avaldub ilmekalt suhtumises võõrasse. Meil on võõras veel nüüdki samatähenduslik külalisega - Läänes on võõras vaenlane, alam olevus, kes tuleb hävitada, alistada, orjastada. Läänele on omane sõja idealiseerimine ja kangelaseaustus, mis läänemeresoomlastel mõeldamatu. Loorits vastandab soomeugrilise monismi ja aarialiku dualismi, rõhutades soomeugrilaste võrd- 
suse põhimõtet ja kooselu loodusega. Loodusjõude antropomorfiseeriti perekonna järgi. Selles kattuvad soomeugrilaste, arktiliste hõimude ja hiinlaste arusaamad: nende sotsiaalne ja usundiline maailmavaade ei taotle võimu või jõuprintsiibi kuritarvitamist, vaid toetub loomistungile. Elu aluseks on mitte valitsemine, vaid sigitamine. Soomeugrilased ei taotle sotsiaalset püramiidi seisuste ja klassidega, vaid võrdset heaolu kõigile. Ka kultuses lähtutakse vastastikusest võrdsusest: ohverdatakse, saamaks vastuteenet. Säilinud palved ei osuta hirmu või alandust, vaid vaimset osalust. Sõnal oli maagiline vägi, sellest sõnumine - vaenulike jõudude tõrjumine või taltsutamine.

Eesti šamanism on kadunud peaaegu jäljetult. On jäänud mõned terminid: transis olek, et hing saaks minna (minestus) ja astuda kontakti surnuhingega (vaimustus), leidmaks nõu ja teateid, või irdhingena otsida kadunud asju, loomi, paremaid jahi- ja kalamaid. Šamaan ei olnud sotsiaalne, poliitiline või sõjaline juht, vaid vaimne mõjustaja, kelle teotsemisväli piirdus arstimise, nõustamise ja ennustamisega.

Soomeugrilaste elutunnet iseloomustab vajaduste tagasihoidlikkus ja rahuldumine piskuga. Õnne ja õnnetust ei käsitatud aarialaste kombel jumala annina või sotsiaalse karistusena. Rahulolematus leidis väljapääsu imaginaarsuses. Muidugi on aegade jooksul tunginud soome-ugri rahvahinge germaanlaste dualism, kuid näiteks polaarsus jumal-kurat on ikka veel põhimõtteliselt võõras ja dogmaatiliselt mõistetamatu. Ürgne monism kajastub ka rahva eetikas. Õigus ja õiglus on meil veel lahutamatud (Kavala-Hansu ja analoogilised pettusel põhinevad lood on hilised laenud). Autunne seostub puhtusega nii kõnedes ja tegudes kui ka soovides ja mõtetes, häbi seevastu mustuse ja räpasusega.

Muistne võitlus ei olnud fanaatiline ususõda, vaid poliitiline vabadussõda. Oluline on see, et meid vallutati ja maeti n.-ö. vaimujää alla siis (1227), kui läänes algas selle jää murenemine (trubaduuriluule, Parzival, islandi saagad, Magna Charta 1215, parlament Inglismaal 1265, Pariisi ülikool u. 1200).

Orjusaeg arendas meie eeldusi vastassuunaliste äärmusteni nii positiivses kui ka negatiivses mõttes. Poliitiline meel spetsialiseerus passiivseks vastupanuks. Ekspluateerimine arendas õiglustunde põikpäise kompromissituseni, laostas rahva eetika. Eetilist dualismi süvendas viha juhtkonna vastu, kes pikkamööda saksastus. Vaesumine tekitas alamuskompleksi ja üldise närvlikkuse kuni degenereerumiseni. Vägivaldne ülemvõim kutsus esile orjameelsuse, mis on tahtejõu haud. Huumor kibestus irooniaks ja sarkasmiks. Heatahtlikkus moondus kiusuks ja pahasoovluseks. Baltisakslus on istutanud meisse "kahjustamise nõiduse", mille aluseks tees: kui mul ei lähe hästi, ärgu mingu ka teistel! Ehk H. Raudsepa sõnastuses: otsekui kreissaega tõmbab südames, kui näed, kuidas teisel hästi läheb. Valitses moonakavaim, mille aluseks on enesesäilitusinstinkt. 
Orjaaeg on meie elutunnet mürgitanud valelikkuse, silmakirjalikkuse, viha ja tigeduse, salakavaluse ja kahjurõõmuga. Kuid need pole olemuslikud meie rahvahingele. Nt. indiaanlased enne valgeid ja meie ei tundnud sõna ega mõistet kade (laen germaani keeltest, nagu ka vaias, hoor, pordik). (Kõige kadedamad maailmas on semi ja aaria hõimud). Mõisamiljöös moondus algselt positiivne jonn (tähenduses meelekindlus) negatiivseks põikpäisuseks. Haiglase äärmuseni paisub orjaajal kalduvus imaginaarsusesse, mis on sisuliselt kompensatsiooni otsimine kujutlustest (nt. rahvalaul "Oleks minu olemine" etc, samuti rahvajuttude mitmed motiivid). Veelgi süveneb juba viikingiajast pärinev sisemine lõhestatus: ühelt poolt liiane trots ja jonn, teiselt poolt pugemine ja lipitsemine. Orjaaeg kitsendas silmapiiri: maailm taandus kodukihelkonnaks.

Tõsi, mitmed hädad on suhteliselt kergesti parandatavad. Üldine närvilisus paraneb ruttu normaalse puhkuse, hea toidu ja julgeolekutunde abil. Moonakavaim kaob peaaegu momentaanselt, kui asemele astub "oma toa - oma loa" võimalus ja mentaliteet. Maailma suhteline piiratus arendas kodukultuuri kõrgtasemeliseks.

Üllatav on O. Looritsa järeldus: kui eestlased ja soomlased suutsid vastu panna järjekindlale ümberrahvustamisele ja jõudsid iseseisvuseni, siis tänu eriti germaani verele ja vaimule nendes, mis andis aktiivsust, organiseerimisvõimet, initsiatiivi ja iseteadlikku uhkust (4, 475). Germaani veri lähtub Looritsa arvates germaanlaste - meeste - püsiasustusest (viikingiajal) Virumaal, hoidmaks oma valduses nn. idateed.

Ühenduses eelnimetatuga tõstab O. Loorits eriti esile eesti naisi. Naised olid soomeugrilaste seas meestega võrdsed, kuid seisundilt olulisemadki: naine säilitas toidutagavara, naine kandis ja vahendas pärimusi, naise hoole all kasvasid lapsed. Need olid naised, kes, abiellunud germaanlastega, need ümber rahvastasid ja kogukonnaga liitsid. Naised kandsid orjaajal laulutraditsiooni. Sestap pole imestada, et kunstluuleski mängivad tähtsat osa naised.

Tõepoolest, kas pole nii, et igal ajajärgul on meil olnud juhtiv naisluuletaja: Koidula, A. Haava, M. Under, B. Alver, D. Vaarandi, D. Kareva.

Looritsa järgi on eesti vaimsus ja kultuurilooming üle elanud kolm suurt murrangut: 1) uurali läänemeresoomlaste lülitumine aaria kultuurimaailma, 2) läänemeresoomlaste formaalne kristianiseerimine koos sellega kaasneva vallutuse ja orjastamisega, 3) rahvuslik renessanss XIX sajandil, murrang, mis kestab senini. Viimases murrangus osundab Loorits kahte suunda. Esimene suund: maagiline mõtteviis taandub igal pool loogilise ees, impressionistlik-mediteeriv elutunne asendub tungiga ennast maksma panna; sugukondlik-kollektiivne vaimsus transformeerub vastupidiseks ekstreemsuseks - individualismiks ja egoismiks; alamuskompleksist lähtuvad opositsioonilisus, salakavalus, tüli- ja kättemaksuhimu, simuleerimine (orjade järglased esinevad aadlikuna, paljas- 
tades igal sammul oma tõusiklikkust). Ühed näevad selles degeneratsiooni, teised imestavad vitaalsust. Tegelikult oli rahvas orjuse tõttu varjusurmas, millest ta tollel murranguajal ärkas tugeva ja kangekaelsena. Teine suund: primitiivne võimuusk, mis tavaliselt modifitseerub jumalausuks, arenes meil edasi omapäraseks kultuuriusuks. XIX sajandi teine pool on eripärane kultuuri ja hariduse apoteoos: kultuuris ja hariduses otsitakse kompensatsiooni või ühendumist jumalikuga (kui teised rahvad otsivad seda poliitikast). Vaevalt orjusest vabanenud rahvas, saanud maa omanikuks, hakkab kirglikult õppima, lugema, kirjutama, luuletama, uurima. Rahvas jäädvustab paberil oma rahvakultuuri ja osaleb tervisest ja kulust hoolimata kultuuriloomingus (seltsid, koolid, teatrid, ERM). Domineerib idealism, ehkki tasakaalustajaks materialism: nälgijate heaks (Soomes 60-ndatel aastatel, Hiinas, Indias, Venemaal) ohverdatakse suuremaid summasid kui näiteks misjoni toetuseks (ehkki viimase taga oli kiriku võimas organisatsioon).

Eesti rahva hinge on vorminud ümbritsev looduslik, majanduslik ja ühiskondlik miljöö, mis on läbi aegade andnud meie olemusse neli ladestust: 1) soomeugriline metsamiljöö ja talvekultuur, millel tugev seos põhja ja ida rahvastega; 2) läänemeresoomelik talupojakultuur, mis tähendab meie kodumaa asustamist, merele avanemist, germaanlastega segunemist ja viimasest johtuvat sisemist lõhestatust; 3) feodaalne orjaaeg moonakavaimu ja vormilise kristianiseerimisega, mis esindab meie olemuse negatiivseid külgi; 4) maarahva ümbersünd eesti rahvaks.

Uurali ja aaria maailma vastuolulisus on lõhestanud meie rahva hinge teadvuse ja alateadvuse, saavutamata sisemist tasakaalu. Hingeline käristatus iseloomustab meie vaimuelu nii totaalselt, et sellest vabanemist pole lähiaegadel lootagi (ainult lätlastel on see veel suurem oma aaria aluspõhja ja soomeugrilise pealispinnaga). Segakultuur levitab hõlpsamini negatiivseid kui positiivseid sugemeid: soomeugrilise sallivuse kõrval baltisaksa sallimatust, heatahtlikkuse kõrval kadedat tigedust, leplikkuse asemel jonni. Peame neid tajuma ja tõstma taas ausse sallivuse ja vastastikuse respekti.

Kokkuvõtvalt leiab O. Loorits, et eestlase iseloomu kujundavad järgmised jooned: ühelt poolt erk loodusetunne, pariteetne suhtumine nii loodusse kui ka kaasinimestesse, kannatlikkus, visadus, ettevaatlikkus, kinnisus ja sügav õiglustunne, aga ka algatusvõime, seiklushimu ja kadedus; teiselt poolt sügavale juurdunud pere- ja kodutunne, aga võimukäsituse nõrkus, organisatsiooniline lõtvus, separatism (partikularism), distsiplineerimatus, alamuskompleks ja moonakavaimu tugevad rudimendid (need on jonn ja lipitsemine, pugemine); kolmandalt poolt rütmitunne ja musikaalsus, meeleolutsemine, pagemine kujutlusmaailma (visionaarsus, imaginatsioon) - teatava kompensatsioonina. 
Lähtudes kolmest n.-ö. üldistatud inimtüübist - voluntaristlik teoinimene, ratsionaalne mõistuseinimene ja emotsionaalne fantaasiainimene - arvab Loorits, et eestlaste (ka teiste soomeugrilaste) seas domineerib nimelt kolmas tüüp, kes on õnnelik oma illusioonides või teoretiseeringutes, millel reaaleluga vähe ühist. Sagedane olevat eestlaste seas süntees kolmanda ja esimese tüübi vahel, kes osutub väga leidlikuks ja initsiatiivikaks (mis iseloomustab eesti majandus- ja spordimehi). Kõige viljakam olevat meil süntees teise ja kolmanda tüübi vahel, mida näitab ühelt poolt loojate (luuletaja, kunstnik, teadlane) suur arv, teiselt poolt rahva osalemine kultuuriloomingus. Väga haruldane on aga esimese ja teise tüübi süntees: seepärast on meil äärmiselt vähe ja harva suuri rahvajuhte, riigimehi, väeülemaid, usukuulutajaid. Pole vist juhus, et meie rahvuslik pidu on laulupidu - mitte olümpiaadid, armee paraadid või poliitilised rahvakogunemised (4, 471-472).

\section{3.}

Mida O. Looritsa kontseptsioonist arvata? Kõige irriteerivam tunnukse väide germaanlaste püsiasustusest Virumaal ja eriti veel germaani "vere ja vaimu" otsustavast osast nii passiivses vastupanus ümberrahvustamisele kui ka rahvuslikus ärkamises.

Eesti arheoloogid ei ole - minu teada-leidnud jälgi germaani asualast Eestis (küll aga Lätis). Möödunud sajandi lõpul esitatud hüpotees "gooti haudadest" on ammu ümber lükatud (pealegi ei olnud need mäletatavasti Virumaal). On tõsi - ja seda rõhutab Loorits ühtepuhku -, et materiaalne kultuur ei võimalda teha ühemõttelisi järeldusi selle kultuuri kandjate etnose kohta. Kuid materiaalne kultuur näitab kultuuripidevust ja viimane ütleb etnose kohta juba rohkem. Teisalt on teada viimase aja antropoloogilistest uurimustest (eriti selle uusimast harust - geeniantropoloogiast) - mis lähtuvad küll enamasti Soome ainesest -, et soomlaste (seda enam ehk eestlaste?) geeniline koosseis on märksa ligemal läänepoolsetele naabritele kui idapoolsetele hõimurahvastele (vt. näiteks E. Grundström). Nii olla soomlastes $85 \%$ geene identsed lääneeurooplastega ja $15 \% \mathrm{nn}$. hõimurahvastega ida poolt. Sellest johtuvalt on püstitatud juba uus "teooriagi” soomlaste (ja küllap siis eestlastegi) päritolust ja rändest. Meil on seda "teooriat" tutvustanud ja levitanud prof. A. Künnap. Geeniuurimus otsekui toetaks O. Looritsa väidet. Igatahes tunnukse see tõenäosem Künnapi esitatust.

H. R. Nevanlinna möönab, et geeniuurimustega hõivatud eestlaste arv on ainult u. $10 \%$ uuritud soomlaste arvust. Ehkki see väljavõttekogum on väike, näitavad geeniuurimused, et eestlased on soomlaste ja "eurooplaste" vahel, mida 
võib tõlgendada nii, et "euroopa" juured on eestlastes tugevamad kui soomlastes. Ilmselt on euroopa rahvastikuelemente sulandunud eestlastesse suuremal määral kui soomlastesse. Ta rõhutab, et see pidi toimuma pärast soomlaste maahõivamist (Soome on teadupärast asustatud sisserändajatega Eestist ja Karjalast). Tähtsamaks peab ta siiski tõendeid eestlaste ja soomlaste ühistest juurtest $(10,166)$. Idapoolsetest soomeugrilastest on mõnevõrra uuritud ainult marisid ja komisid ning Siberi rahvaid. Nende võrdlusandmete põhjal järeldab Nevanlinna, et rohkem kui neljandik (aga vaevalt et kolmandik) soomlaste juurtest on mitte-euroopa päritolu. Kuna puudub usaldatav "geneetiline kell”, pole võimalik kindlaks määrata euroopa geeni-ainese otsest tulekuaega (10, 167). Ka see arutlus toetab O. Looritsa väiteid.

Mõistagi on õige väide, et miljöö määrab suuresti ka iseloomu. Aga kas poleks õigem arvata, et talupoja eluolu - erinedes oluliselt küttija-kalastaja eluolust - on ise kujundanud aastatuhandete vältel läänemeresoomlase elutunnet ja vaimulaadi ilma germaanlaste mõjuta (vähemalt olulise mõjuta)? On kahtlane uskuda, et metsamiljõõ mõju on säilinud üle aastatuhandete põlluharijate vaimus ja meelelaadis. See kisuks vägisi vanaks vaidluseks: kumb on olulisem, kas miljöö (+kasvatus) või pärivus. Loorits näib uskuvat viimast. Aga kui geenid on juba teised, kuidas sai siis püsida metsakultuuri vaimsus? Kas meis on $15 \%$ muistset soomeugrilist metsavaimsust (seda juhul, kui eestlaste geenide suhe on samasugune nagu soomlastel)? Ei oska näha ka germaan- lastes hitlerlikke "üliinimesi", kelle ideaaliks on ainult sõja ülistamine, vallutamine ja egoistlik eneseigavikustamine (vt. ka 1, 501-508).

Kahtlemata on O. Looritsa eestlase iseloomustus küllalt meeldiv, et mitte öelda meelitav. Küllap on siin ka palju õigeid tähelepanekuid, eriti selles osas, mis seostub nn. orjaajaga. Teisalt kipub käsitluses läbi lööma isesugune soome-ugri "rassism". Ka välismaised arvustajad (I. Paulson, R. T. Christiansen, W.-E. Peuckert) kahtlevad uurali ja aaria hinge jäigas vastandamises ning osutavad sotsiaalmajanduslike tegurite vähesele arvestamisele.

Võrdluseks toon siis mõned Uku Masingu seisukohad. Oma "Eesti usundis" seab U. Masing Looritsa kogu baasmaterjali kahtluse alla, väites: "On siis üldse küsitav, kas me jõuamegi mingi eesti usundi juurde kunagi. Sest kui kõige vanemad osad meie pärimusist põlvnevad kuskilt Paabelist, siis on võimalik oletada sama ka teiste soome-ugri rahvaste kohta juba eo ipso, kes olid veelgi lähemal idale. Sellega on kadunud ainus vahend määrata, et mingi uskumus on soomeugrilik, sest seda ta oleks ainult siis, kui pääle eestlaste teda leiduks ka teiste soomeugri rahvaste juures... Veel raskem on siis määrata muidugi spetsiifilist eestilist, võime öelda rahulikult, et praegusis tingimusis täiesti võimatu on öelda, mis on tekkinud eestlaste eneste hingest. Oleme konglomeraat väga vanu Ida laene, laene varasilt germaanlasilt, laene Bütsantsist venelaste 
ja viikingite kaudu, laene hilisemailt germaanlasilt ja osalt ka venelasilt. Kuid mis on oluline meile endile või soomeugri rahvaile, on peaaegu võimatu määrata ja kõik, mida kavatseme nimetada nõnda, mõne aasta pärast võib kujuneda laenuks muistselt Idamaalt" (8, 8-9).

Seesuguse absoluutse kahtluse kõrval tunduvad teksti poetatud kriitilised märkused tagasihoidlikud: "Ei ole vaja arvata, et kujutlused surnute maailmast on tekkinud germaani mõjul” $(8,94)$ või “...ka Eestis ei koheldud surnuid sõpradena, vaid olenditena, kes olid arvestamatud. Looritsal on õigus, et nende muutumine kurjemaks kui enne on tingitud ristiusu ja sellega germaani maailma mõjust, kuid mitte iial säärases ulatuses kui tema arvab" (8, 111-112) või “Oleme üksi, sest elusate seas pole sõpru peaaegu ühelgi meist, vaid ainult vaenlasi, kadetsejaid ja muid selliseid olendeid, kellede olemasolu Loorits ehk liig suures ulatuses ajab süüks sakslastele" $(8,113)$.

Silmas pidades Masingu vastasseisu indogermaanlastega ülepea, on need märkused tõsiselt arvestatavad. Paraku peab nentima, et Masingu kriitika käib Looritsa varasemate tööde kohta. Looritsa peateost ei nimeta Masing minule kättesaadaval olnud töödes mitte kunagi. On mõeldav, et mõni Masingu arvukatest käsikirjadest käsitleb nimelt Looritsa peateost ja selle probleeme. Kahtlevas suhtumises soomeugri ja eesti usundi algupärra avaldub ühel ajajärgul Masingule omane nihilistlik pessimism (või pessimistlik nihilism); üksikmotiivid usundis võivad tõesti osutuda kasvõi kõik laenuliseks, kuid usundisüsteem - motiivide omavaheline seostumine ja suhe - on siiski algupärane. Teadaolevalt leidub tema artiklites siin-seal vihjeid, tähelepanekuid, karakteroloogiaga seonduvaid märkusi. Üllatavalt mitmed on üsnagi lähedal Looritsa väidetele. Järgnevalt näited teosest "Vaatlusi maailmale teoloogia seisukohalt" (kogumikus "Pessimismi põhjendus" sellealaseid täheldusi ei leidnud).

Keelepsühholoogiat arutades järeldab Masing sugude puudumisest eesti keeles: "Eestlane ei taipa mitte mõistuse ega klassifitseeritud kataloogi järele, vaid kuidagi intuitiivselt (minu sõrendus - Ü. T.), ta ei eralda ennast maailmast, vaid saab ka enda asetada maailma. (Sellest aga järgneb ka, et eestlastest ei saa valitsevat rahvast, ta ala on alatiseks vaatlus ja metafüüsika). Oleme lähemal hiinlastele kui eurooplastele, tendeerime monismi poole (meie "väga" ja "vähe" - kuigi vastastähendustega - on ka samast tüvest)" (9, 53). Samas, lähtudes tulevikuvormi puudumisest, sedastab Masing: "Selletõttu on eestlane staatiline... Eestlasel puudub faustiline tung lõpmatusse, alaline teelolemise, muutuvuse tunne, ta ei heitle ajaga nagu indogermaan. - Selle asemel asetab ta enda ajast üle... Võitleva arengu asemel vaid lihtne astumine üle aja piiride, väljaspoole liikuvust... eestlane võib küll arenguõpetusest aru saada, aga ta võtab seda egoistlikult, indogermaan aga sotsiaalselt, kuna semiit tast üldse aru ei saa... Kriisiaegadel eestlase suhtumine aega võib muutuda massili- 
seks endatapmiseks, muidu aga avaldub aeganärivas jonnis, monumentaalsuse ja kindluse püüdes” (9,53-54). Meie objektikasutusest järeldab Masing: “... eestlasele on tähtis toimingu intensiteet, mitte aga toiming ise; teda ei huvita niipalju see, et midagi juhtub, vaid kuidas see juhtub" $(9,54)$. Lõpetuseks väidab ta: “... meie tigukarp on mingi monistlik müstiline religioossus, oleme kuidagi ekstaatilist loomu, aga meil pole ta tormitsev, vaid rahulik, kuidagi fatalistlik. Me oskame nähteid hinnata intensiteedi järgi, pole tähtis kavatsus mingi teo juures, mitte ka niipalju teo tulemus, vaid see viis, kuidas midagi tehakse. Kui religioon ja moraal on vastandid, mida nad on muidugi, siis - eestlane on lähemal religioonile kui moraalile. Rikkumata eestlane ei usu kunagi eetika süsteeme, mis läänes aga endastmõistetavad. Inimene pole ju maailma keskpunkt, vaid just niisama palju väärt kui linnud ja puud...” $(9,54)$.

Teisal märgib Masing: selgemini tajutav joon eestlaste vagaduses on ekstaatilisus, mis tähendab inimese mina piiride avardamist $(9,92)$, või rõhutab, et eestlane ei tunne piire enda ja ümbritseva vahel $(9,94)$, et ühtlustunne loodusega on nii suur, et allegooria seletamist ei peeta vajalikuks $(9,96)$. Masing näeb eestlase loomuomaduses sõbralikkust kõige oleva vastu $(9,98)$. Ta väidab: kui eestlasel on hea - siis ta ei oskagi paremat soovida, kui halb - siis ta ei suuda seda $(9,102)$. Igatahes pole maailmaparandamiskavad ja -katsed eestiomased.

Fraashaaval võiks ju kogumikust noppida veelgi, aga need on suuresti korduvad, ütlevad juba öeldut teiste sõnadega. Olen siingi ära jätnud argumentatsiooni ja esitanud järeldused. Kokkulangevus Looritsa ja Masingu seisukohtades on küllaltki suur. Erisus avaldub selles, et Loorits taotleb esitada eesti iseloomu ajaloolist kujunemist, Masing aga läbilõiget 30-ndate aastate (uskliku) eestlase iseloomust.

Kuidas me O. Looritsa suurejoonelist skeemi ka ei hindaks, igal juhul tuleb möönda, et tegemist on põhjaliku, sealjuures järjekindla ja lõpuni viidud käsitlusega eesti iseloomust ja seda põhjustanud teguritest. On hoopis iseküsimus, kas seda skeemi on võimalik täiendada ja parandada. Kui omaks võtta Looritsa baasseisukoht soome-ugri hingest või sellega leppida, siis on täiendamine muidugi võimalik. Kui see on vastuvõtmatu, siis tuleb luua uus skeem. See ei vähenda mingil juhul Looritsa teeneid. Kriitikud on Looritsale ette heitnud liigset fantaasiat. Teisalt võib küsida: kas on sellist käsitlust ülepea võimalik kirjutada ilma fantaasiata! Igatahes on folkloor kõige laiemas mõttes väga tänuväärt materjal ka rahvapsühholoogiliselcs uurimiseks. Alati on võimalik kirjutada uuem käsitlus. Aga kas ka parem?

Küll aga peaksid tänased riigijuhid ja muud prominendid tutvuma Looritsa (ja teiste) vastavate seisukohtadega. Võibolla oleks sellest kasu! 


\section{Kommentaar}

1 Praegu naiivsena tunduv teos avaldas ilmumisajal positiivset mõju. Vt. näiteks K. A. Hindrey, Tõnissoni juures (Elu kroonika V). Tartus, 1931, lk. 174. Muide, ka Hindrey on teinud mõningaid otsustusi eestlase iseloomu kohta, seda küll Tartu eesti seltskonna põhjal sajandi alguses.

\section{Kirjandus}

1. Annist, A., Moora, H. Teos eesti rahvausundi uurimise alalt // Keel ja Kirjandus. 1965. Nr. 8.

2. Grundström, E. Geenit menivat, kieli jäi // Hiidenkivi. 1995. Nr. 6.

3. Kampmann, M. Eestlase iseloom ja laad. Jurjev (Tartu), 1902.

4. Loorits, O. Grundzüge des estnischen Volksglaubens I-III // Skrifter Utgivna av Kungl. Gustav Adolfs Akademien 18: 1, 2, 3. Lund 1949, 1951, 1957.

5. Loorits, O. Eestluse elujõud // Iseseisvuslaste Kirjavara. 1951. Nr. 5.

6. Loorits, O. Eesti ajaloo põhiprobleemid // Iseseisvuslaste Kirjavara. 1955. Nr. 11.

7. Luiga, J. Mäss ja meelehaigus / Koostanud H. Runnel, toimetanud K. Ligi ja M. Trummal / Tartu, 1995.

8. Masing, U. Eesti usund. Tartu, 1995.

9. Masing, U. Vaatlusi maailmale teoloogi seisukohalt. Tartu, 1993.

10. Nevanlinna, H. Suomalaisten juuret geneettisen merkki ominaisuustutkimuksen valossa // Suomen kansan esihistorialliset juuret. Helsinki, 1984.

11. Semper, J. Prantsuse vaimulaad ja meie rahvuslik omapära // Semper, J. Prantsuse vaim. Tartu, 1934. 